\title{
Analisis Performa Bilah Taperless Dengan Airfoil NACA 4412 Pada Horizontal Axis Wind Turbine TSD 500 Di PT Lentera Bumi Nusantara
}

\author{
Muhammad Alfi Alfaridzi ${ }^{1}$, Reza Setiawan ${ }^{2}$ \\ ${ }^{1,2}$ Universitas Singaperbangsa Karawang \\ 1,2 Program Studi Teknik Mesin Universitas Singaperbangsa Karawang \\ e-mail: *1710631150015@student.unsika.ac.id
}

\begin{abstract}
Abstrak: Kecepatan angin di wilayah Indonesia hanya berkisar 3 meter/s sampai 11 meter/s, cukup sulit untuk menghasilkan listrik untuk skala besar, hal itu juga yang membuat pemanfaatan energi angin masih sangat rendah. Tetapi potensi angin di Indonesia tersedia hampir sepanjang tahun, sehingga ada kemungkinan pengembangan teknologi untuk memanfaatkan energi tersebut dengan beberapa keterbatasan tadi. Modifikasi kincir angin perlu dilakukan yang disesuaikan dengan kondisi kecepatan angin yang rendah untuk dapat menghasilkan energi listrik yang optimal. Oleh sebab itu, dibuat rancangan bilah HAWT (Horizontal Axis Wind Turbine) menggunakan airfoil NACA yang memiliki nilai $\mathrm{Cl} / \mathrm{Cd}$ yang tinggi untuk menghasilkan daya $500 \mathrm{~W}$ pada kecepatan angin 1 meter/s - 11 meter/s. Penelitian dilakukan dalam 3 tahap. Pertama tahap perhitungan untuk menentukan jari - jari, chord dan twist bilah. Kedua tahap perancangan awal bilah dilakukan secara simulasi dengan menggunakan software QBlade untuk menentukan airfoil NACA yang digunakan serta mengetahui coefficient performance dan daya yang dihasilkan. Ketiga tahap perancangan bilah menggunakan software solidworks yang menghasilkan desain 3D bilah. Hasil perancangan menghasilkan bilah HAWT dengan airfoil NACA 4412 jenis taperless dengan jari - jari bilah $1 \mathrm{~m}$, , lebar chord 0,12 m, dan twist angle $5,08^{\circ}-12,08^{\circ}$. Pada kecepatan angin $10 \mathrm{~m} / \mathrm{s}$, bilah memiliki Cp maksimum 52\%, daya maksimum 1010 W pada kecepatan sudut $450 \mathrm{rpm}$, daya minimum $85 \mathrm{~W}$ pada kecepatan sudut $95 \mathrm{rpm}$. Rata-rata daya yang dihasilkan yaitu sebesar 547,5 W. Hasil pengujian lapangan bilah Taperless NACA 4412. Hasil pengujian di lapangan didapatkan maksimum daya pengisian sebesar $585.58 \mathrm{~W}$ dan pengisian daya rata-rata berkisar 30.24 $\mathrm{W}$, dengan daya yang dihasilkan sebesar $725.55 \mathrm{Wh}$.
\end{abstract}

Kata kunci: Bilah, Taperless, NACA 4412, Turbin Angin

\begin{abstract}
The wind speed in Indonesia is only around 3 meter / s to 11 meter / s, it is quite difficult to produce electricity on a large scale, this also makes wind energy utilization very low. However, the potential for wind in this country is available almost all year round, so there is the possibility of developing technology to utilize this energy with some of these limitations. Windmills need to be modified according to low wind speed conditions to produce electrical energy. Therefore, a Horizontal Axis Wind Turbine (HAWT) blade design was made using a NACA airfoil which has a high $\mathrm{Cl} / \mathrm{Cd}$ value to produce $500 \mathrm{~W}$ of power at wind speeds of 1 meter/s - 11 meter / s. there are 3 stages of research this time. The first calculation phase is to determine the radius of blade, chord and twist of airfoil. The two stages of the initial blade design were simulated using QBlade software to determine the NACA airfoil being used and to determine the performance coefficient and the resulting power. The three stages of blade design use Solidworks software which produces a 3D blade design. The design results produce a HAWT blade with a taperless NACA 4412 airfoil with blade radius of 1 $\mathrm{m}$, chord width $0.12 \mathrm{~m}$, and twist angle of $5.08^{\circ}-12.08^{\circ}$. At a wind speed of $10 \mathrm{~m} / \mathrm{s}$, the blade has a maximum $\mathrm{Cp}$ of $52 \%$, a maximum power of $1010 \mathrm{~W}$ at an angular speed of $450 \mathrm{rpm}$, a minimum power of 85 $\mathrm{W}$ at an angular speed of $95 \mathrm{rpm}$. The average power produced is $547.5 \mathrm{~W}$. Field test results of Taperless NACA 4412 blades. The results of the field testing are $585.58 \mathrm{~W}$ of maximum charge and an average charge of $30.24 \mathrm{~W}$, with the resulting power of $725.55 \mathrm{Wh}$
\end{abstract}

\section{Keywords: Blade, Taperless, NACA 4412, Wind Turbine}

Energi angin diperoleh dari hasil setengah kali massa jenis udara dengan luas penampang dari bilah dan pangkat tiga dari kecepatan angin pada saat terjadinya (Tim Lentera Angin Nusantara, 2014). Sedangkan energi mekanik yang diperoleh sebuah turbin angin nilai nya sebesar perkalian kecepatan putar bilah dengan torsi (gaya yang diberikan oleh lengan bilah turbin 
angin). Salah satu Turbin angin dengan efisiensi tinggi yaitu bertipe horizontal dan menggunakan jenis bilah yang memiliki effisiensi (Cp) cukup tinggi yang mendekati $45 \%$ bahkan dalam teori bezht bias mencapai 59\% yaitu tipe tiga Blade Proppeler. Apabila di artikan, semakin tinggi effisiensi suatu bilah turbin maka semakin maksimal juga dalam mengkonversi energy angin tersebut.

Tetapi Kecepatan angin rata rata di Indonesia hanya sebesar 3m/s-6 m/s (Tim Lentera Angin Nusantara, 2017) yang termasuk dalam kategori rendah (Kementerian Energi dan Sumber Daya Mineral, 2016), maka dari itu sangat perlu di perhatikan masalah distribusi kecepatan angin di Indonesia Untuk menentukan desain sebuah bilah yang tepat, untuk mengkonversi energi angin ke energi mekanik yang nantinya akan di konversi menjadi listrik oleh generator, maka di perlukan bentuk desain bilah yang paling optimal. Bilah sendiri memiliki 3 jenis desain yang berbeda, berdasarkan luas penampangnya yaitu taper, taperless, dan inversetaper, juga memiliki bentuk geometri berupa lekukan unik seperti tetesan air, pada bagian ujung depan, bentuk ini bisa kita lihat pada bagian depan bilah yang disebut dengan Airfoil, bentuk ini mempengaruhi efisiensi bilah, yaitu daya angkat bilah terhadap energi angin yang menerpa. Dalam perancangan suatu bilah ada beberapa aspek yang perlu dipahami yaitu mekanika fluida, aerodinamika dan materialnya dan untuk menganalisa suatu turbin angin ada beberapa variable yang perlu di perhatikan seperti Tip Speed Rasio(TSR), twist, Angel of attack, power coefficient (Cp), panjang bilah, Airfoil dan lainnya.

Di PT. Lentera Bumi Nusantara (LBN) yang terletak di desa Ciheras, Cipatujah, Tasikmalaya, Jawa Barat mengembangkan energi terbarukan khususnya Pembangkit Listrik Tenaga Bayu (PLTB) skala mikro. Turbin angin skala kecil sendiri merupakan turbin angin yang memiliki luas sapuan kurang dari $200 \mathrm{~m} 2$ dan menghasilkan tegangan kurang dari 1000 volt atau 1500 volt DC (A. Sanchez-Miralles, C. Calvillo, F. Martín, dan J. Villar,s, 2014). Rata-rata angin di pantai ciheras sekita $12 \mathrm{~m} / \mathrm{s}$ dengan turbin angin yang didesain untuk TSR 7 (Tim Lentera Angin Nusantara, 2014).Turbin angin skala kecil dipilih karena nilai investasinya relatif kecil dan pembangunannya relatif mudah bila dibandingkan dengan turbin angin skala besar. Saat ini, turbin angin modern mengaplikasikan prinsip aerodinamis pada bilah sehingga konversi energi menjadi lebih efisien. Gaya gaya yang bekerja pada bilah turbin angin diantaranya gaya angkat dan gaya hambat. Dalam perancangan bilah, hal yang dicari adalah nilai sudut serang pada airfoil yang memiliki nilai koefisien angkat per koefisien hambat Glide Ratio (GR) tertinggi,

Di PT Lentera Bumi Nusantara ini tipe airfoil yang biasa di pakai yaitu tipe clark y, NACA 4412, NACA 4415 Dan NACA 3610. Salah satu jenis airfoil yang disarankan untuk kecepatan angin rendah dengan nilai GR yang tinggi dan stabil terhadap perubahan bilangan Reynolds dan sudut serang adalah NACA 4412. Dalam penelitian ini akan menganalisis performa airfoil yaitu NACA 4412 untuk turbin angin tipe horisontal dengan jenis bilah taperless, skala mikro TSD 500 Watt menggunakan software Q-blade di Ciheras, PT. Lentera Bumi Nusantara untuk mengetahui airfoil yang baik untuk digunakan. Dalam penelitian ini, bilah turbin angin yang jenis airfoil nya NACA 4412 dikombinasikan dan diuji dengan Permanent Magnet Synchronous Generator (PMSG) cogging-less untuk mendapatkan efisiensi yang tinggi sehingga turbin angin dapat berotasi pada kecepatan angin yang minim.

\section{METODE}

\section{Tahapan Persiapan}

Studi Literasi

Studi literasi mengenai konsep Pembangkit Listrik Tenaga Bayu (PLTB), mekanisme pemanfaatan energi angin, komponen-komponen kincir angin, dan parameter-parameter dalam perancangan bilah kincir angin.

\section{Analisis Karakteristik Airfoil}

Pada tahap ini, dilakukan analisa karakteristik airfoil menggunakan software $Q$-Blade. Karakteristik yang dianalisa yaitu grafik perbandingan lift force dan drag force terhadap sudut serang $(\mathrm{Cl} / \mathrm{Cd}-\alpha)$, serta grafik lift force terhadap sudut serang $(\mathrm{Cl}-\alpha)$. Tujuan pada tahap ini adalah untuk melihat kecenderungan dari airfoil terhadap lift force dan drag force-nya 


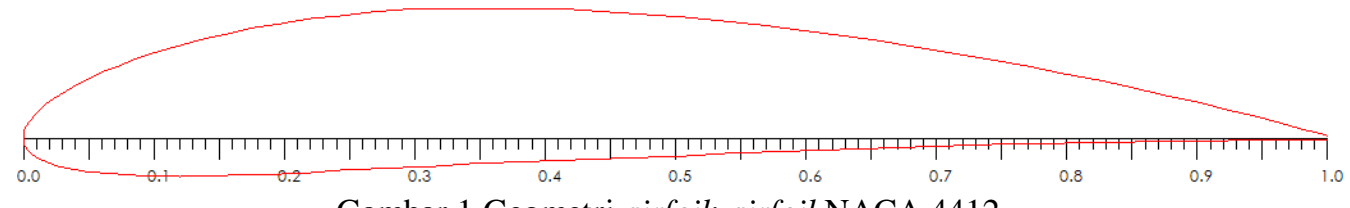

Gambar 1 Geometri airfoil; airfoil NACA 4412

Langkah awal dalam menentukan geometri bilah yaitu dengan mengetahui besar sudut serang $(\alpha)$ dan Lift Coefficient (Cl). Nilai tersebut didapatkan dari hasil simulasi menggunakan software Q-Blade v0.963. Sudut serang sendiri merupakan sudut datangnya tumbukan angin terhadap airfoil, coefficient lift $(\mathrm{Cl})$ sendiri merupakan nilai koefisiensi gaya angkat pada bilah. Untuk dapat berotasi nilai gaya angkat harus lebih besar dibanding gaya hambatnya (coefficient drag) (Burhannudin Dahlan, 2016). Hasil simulasi airfoil NACA 4412, tersaji pada Gambar 2 sebagai berikut.
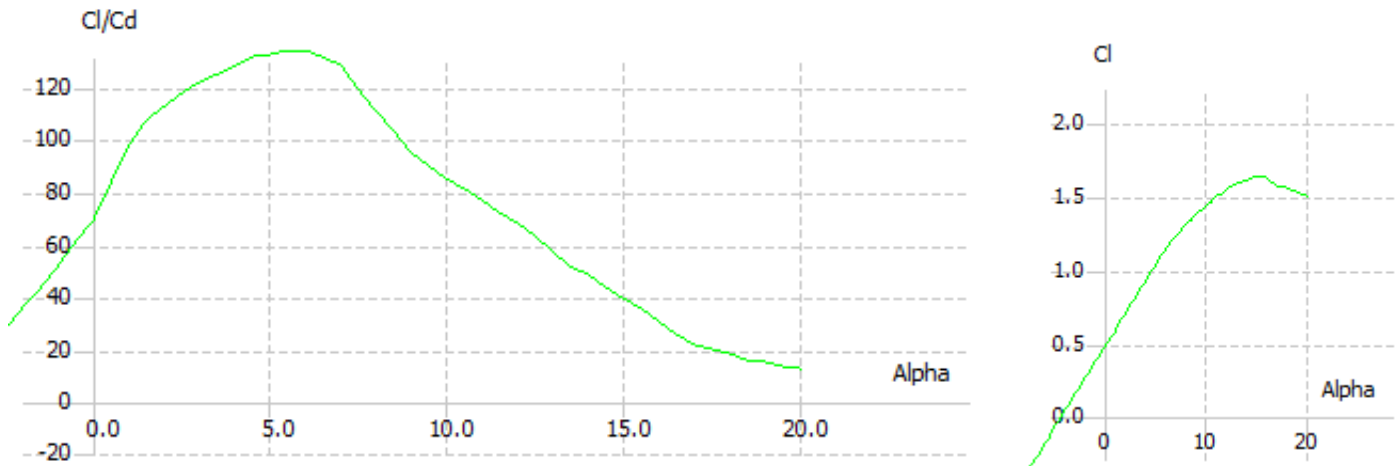

Gambar 2 Hasil simulasi airfoil NACA 4412

Dari Gambar 2 terlihat bahwa Cl/Cd optimual yaitu pada seri NACA 4412. Lift coefficient akan naik ketika alpha naik, lalu kemudian turun setelah mencapai titik tertentu, hal itu disebabkan adanya stall yaitu ketika $\mathrm{Cl}$ sudah mencapai optimum dan tidak bertambah sedangkan Cd masih terus bertambah.

\section{Perhitungan}

Sebelum melakukan pendesainan bilah, terlebih dahulu menentukan parameter-parameter yang akan digunakan sebagai dasar perancangan geometri bilah. Parameter tersebut antara lain yaitu :

Daya angin yang dibutuhkan $\left(P_{a}\right)$

$$
\begin{aligned}
& P_{a}=\frac{P_{l}}{K} \\
& P_{a}=\frac{1}{2} \rho A v^{3}
\end{aligned}
$$

dimana :

$P_{a}=$ Daya angin yang dibutuhkan $(W)$

$P_{l}=$ Daya listrik yang ingin dihasilkan $(W)$

$K=$ efisiensi sistem

$\rho=$ densitas udara $\left(\mathrm{Kg} / \mathrm{m}^{3}\right)$

$A=$ luas sapuan bilah $\left(\mathrm{m}^{2}\right)$

$v=$ kecepatan angin $(\mathrm{m} / \mathrm{s})$

Efisiensi sistem kincir angin $(K)$

$$
K=\eta_{b} \times \eta_{g} \times \eta_{t} \times \eta_{k}
$$

dimana :

$K=$ efisiensi sistem

$\eta_{b}=$ efisiensi bilah 
$\eta_{g}=$ efisiensi generator

$\eta_{t}=$ efisiensi transmisi

$\eta_{k}=$ efisiensi kontroler

Tip Speed Ratio / TSR ( $\lambda$ )

TSR sendiri merupakan perbandingan antara kecepatan linear di ujung bilah terhadap kecepatan angin, yang ditunjukkan oleh persamaan (4) berikut :

$$
\lambda=\frac{\omega \times R}{v}
$$

dimana :

$\omega=$ Kecepatan sudut $(\mathrm{rad} / \mathrm{s})$

Selanjutnya penentuan parameter geometri bilah dilakukan dengan didasarkan pada parameter di atas. Pada bagian ini, bilah dibagi menjadi 11 elemen (1 elemen pangkal dan 10 elemen sama panjang). Geometri yang dihitung yaitu :

Jari-jari bilah $(R)$

Dari persamaan (2) akan didapat persamaan untuk mencari jari-jari bilah (R), yang ditunjukkan oleh persamaan (5) sebagai berikut :

$$
\begin{aligned}
A & =\frac{2 P_{a}}{\rho v^{3}} \\
R=\sqrt{\frac{A}{\pi}} &
\end{aligned}
$$

dimana :

$A=$ luas sapuan bilah $\left(m^{2}\right)$

$R=$ jari-jari bilah $(m)$

\section{TSR Parsial}

TSR parsial merupakan perbandingan antara kecepatan linear elemen bilah terhadap kecepatan angin pada elemen yang berbeda beda.

dimana :

$$
\lambda_{r}=\frac{r}{R} \lambda
$$

$\lambda_{p}=$ TSR parsial

$r=$ jari - jari parsial

\section{Koefisien Lift tiap elemen $(\mathrm{Cl})$}

Nilai koefisien lift $(\mathrm{Cl})$ untuk tiap elemen bilah menggunakan persamaan (7) sebagai berikut :

dimana :

$$
C_{l}=\frac{16 \pi \times R \times(R / r)}{9 \lambda^{2} \times B \times C r}
$$

$\mathrm{Cl}=$ koefisien $l i f t$

$\mathrm{B}=$ jmlah bilah

$\mathrm{Cr}=$ lebar bilah / chord

Sudut serang $(\alpha)$

Sudut serang ditentukan dengan melihat grafik Cl- $\alpha$ yang didapat dari analisa airfoil dengan software Q-Blade. 
Flow Angle $(\phi)$

Flow angle untuk masing-masing elemen didapat dari persamaan (8) sebagai berikut :

dimana :

$$
\phi=\frac{2}{3} \tan ^{-1} \frac{1}{\lambda_{p}}
$$

$\phi=$ Flow angle

$\lambda_{p}=$ TSR parsial

\section{Sudut puntir / Twist ( $\beta)$}

Twist untuk masing-masing elemen didapat dengan persamaan (9) sebagai berikut :

dimana :

$$
\beta=\phi-\alpha
$$

$\beta=$ Twist

$\alpha=$ Sudut serang

Efisiensi sistem merupakan penentuan paramameter awal untuk melakukan perancangan bilah. Efisiensi sistem merupakan efisiensi gabungan dari efisiensi bilah, efisiensi generator, efisiensi transmisi dan controller, menurut (AlShemmeri, 2010) bilah hanya dapat mengekstrak energi maksimum sebesar 59\% atau disebut juga koefisien Betz (Cp). Pada perancangan kali ini efisiensi bilah dimasukkan 2 nilai, yaitu saat efisiensi rendah (dipakai 20\%) dan efisiensi tinggi (40\%). Efisiensi Transmisi adalah $100 \%$ dikarenakan putaran dari bilah langsung terhubung dengan generator dan tidak menggunakan transmisi, sedangkan efisiensi generator dan controller memiliki nilai efesiensi yang berbeda tergantung jenis yang digunakan. Pada perancangan kali ini nilai efisiensi generator dan controler dibuat 90\%. Efisiensi sistem keseluruhan yaitu dengan mengalikan efisiensi keempatnya, yang ditunjukkan pada persamaan (3) diperoleh efisiensi sistem sebesar 16.2\% ketika efisiensi bilah $20 \%$ dan $32.4 \%$ ketika efisiensi bilah $40 \%$.

Bila efisiensi sistem sudah didapatkan, selanjutnya kita menentukan kapasitas daya listrik yang diiginkan (Pl) yaitu sebesar $500 \mathrm{~W}$ dengan kecepatan angin maksimal sesuai kondisi lapangan sebebsar $10 \mathrm{~m} / \mathrm{s}$. Daya angin yang dibutuhkan (Pa) didapat dengan persamaan 1 dan didapat hasil sebesar $3086.42 \mathrm{~W}$ jika efisiensi bilah $20 \%$ dan $1543.21 \mathrm{~W}$ jika efisiensi bilah $40 \%$. Setelah itu, dicari panjang bilah dengan persamaan (2) didapat panjang bilah yang dibutuhkan untuk efisiensi bilah $20 \%$ yaitu 1,26 m dan untuk efisiensi bilah $40 \%$ sebesar $0,89 \mathrm{~m}$. Dapat diputuskan untuk panjang bilah pada perancangan kali ini sepanjang 1 meter $(\mathrm{R})$ dengan acuan di ambil nilai tengah, ntuk mendesain sebuah bilah dengan airfoil NACA 4412 dengan jenis bilah taperless. Parameter data penentuan panjang bilah terangkum pada Tabel 1 berikut.

\begin{tabular}{|c|c|c|c|c|c|c|c|c|c|c|c|}
\hline \multirow{2}{*}{$\begin{array}{c}P_{l} \\
\text { (watt) }\end{array}$} & \multicolumn{4}{|c|}{ Efisiensi } & & \multirow{2}{*}{$P_{a}$ (watt) } & \multirow{2}{*}{$\begin{array}{c}\mathrm{v} \\
(\mathrm{m} / \mathrm{s})\end{array}$} & \multirow{2}{*}{$\rho\left(\mathrm{kg} / \mathrm{m}^{3}\right)$} & \multirow{2}{*}{$\begin{array}{c}\text { A } \\
\left(m^{2}\right)\end{array}$} & \multirow{2}{*}{$\begin{array}{c}\mathrm{R} \\
(\mathrm{m})\end{array}$} & \multirow{2}{*}{$\begin{array}{c}\mathrm{R} \\
(\mathrm{m})\end{array}$} \\
\hline & Bilah & Generator & Transmisi & Controller & Sistem & & & & & & \\
\hline \multirow{2}{*}{500} & 0.2 & \multirow{2}{*}{0.9} & \multirow{2}{*}{1} & \multirow{2}{*}{0.9} & 0.162 & 3086.42 & \multirow{2}{*}{10} & \multirow{2}{*}{1.225} & 5.04 & 1.26 & \multirow{2}{*}{1} \\
\hline & 0.4 & & & & 0.324 & 1543.21 & & & 2.52 & 0.89 & \\
\hline
\end{tabular}

Tabel 1 Penentuan parameter awal bilah

\section{Perancangan Model}

Pada tahap ini, perancangan model bilah meggunakan software Q-Blade v0.963 dengan memasukkan dimensi tiap elemen dilakukan. Selanjutnya menentukan TSR. TSR akan diestimasi pada tahap ini. Namun pada akhir simulasi nanti TSR dapat berubah. Estimasi TSR dapat dilakukan dengan melihat referensi bahwa TSR untuk turbin angin dengan 3 bilah berkisar pada rentang 6-8 (Tim Lentera Angin Nusantara, 2017) Pada analisa kali ini dimasukkan nilai TSR sebesar 7.

Setelah itu didapatlah jari-jari parsial dan twist di tiap elemennya. Twist yang didapat ternyata tidak membentuk garis linear. Hal itu akan menyulitkan proses pembuatan bilah, sehingga perlu dilakukan optimasi sudut twist dengan linearisasi garis. Optimasi twist ditunjukkan oleh Gambar 3berikut. 


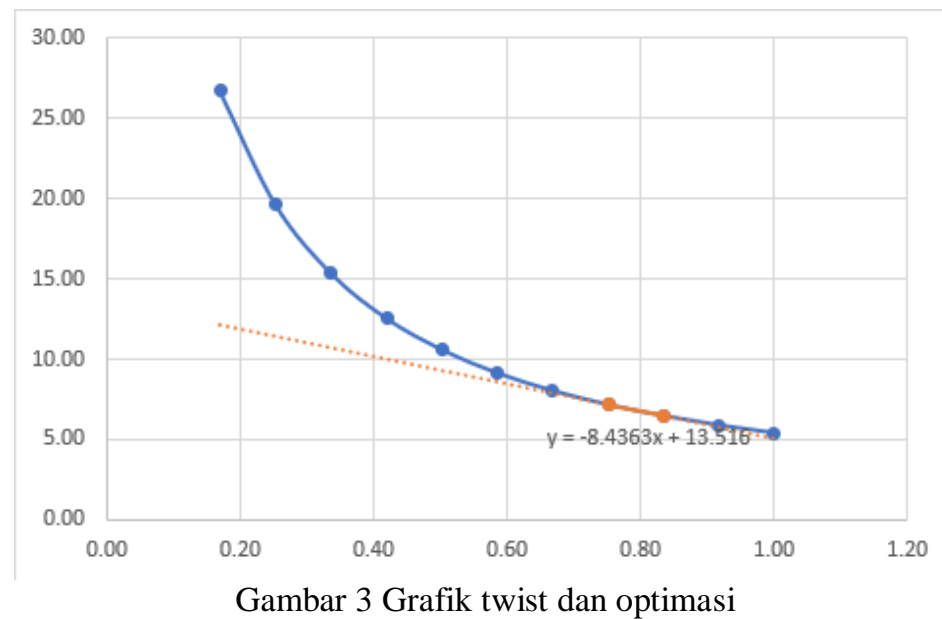

Penentuan geometri bilah secara lengkap ditunjukkan pada Tabel 2 berikut.

Tabel 2 Penentuan geometri perancangan bilah

\begin{tabular}{|c|c|c|c|c|c|c|c|c|}
\hline \multirow{3}{*}{ Elemen } & \multirow{2}{*}{$\begin{array}{c}\text { TSR } \\
7\end{array}$} & \multicolumn{2}{|c|}{ Airfoil } & $\begin{array}{c}\mathrm{Cr} \\
0.12\end{array}$ & \multirow{2}{*}{\multicolumn{2}{|c|}{ Jumlah Bilah }} & \multirow[b]{3}{*}{$\begin{array}{l}\text { Twist } \\
\text { Liner } \\
75 \% \\
\end{array}$} & \multirow[b]{3}{*}{$\begin{array}{l}\text { Twist } \\
\text { Liner } \\
75 \%\end{array}$} \\
\hline & & \multicolumn{2}{|c|}{ NACA 4412} & 3.6 & & & & \\
\hline & $\begin{array}{c}\text { Jari jari } \\
\text { parsial(r) }\end{array}$ & $\begin{array}{c}\text { TSR } \\
\text { Parsial }\end{array}$ & Cl Parsial & Alpha $\alpha$ & $\begin{array}{c}\text { Flow } \\
\text { Angel } \phi\end{array}$ & $\begin{array}{c}\text { Twist } \\
\beta\end{array}$ & & \\
\hline 0 & 0.17 & 1.19 & 1.86243 & 7.2 & 26.69 & 26.69 & & 12.082 \\
\hline 1 & 0.25 & 1.77 & 1.251435 & 3.2 & 19.63 & 19.63 & & 11.382 \\
\hline 2 & 0.34 & 2.35 & 0.942301 & 1.325 & 15.36 & 15.36 & & 10.681 \\
\hline 3 & 0.42 & 2.93 & 0.75564 & 0.23 & 12.55 & 12.55 & & 9.981 \\
\hline 4 & 0.50 & 3.51 & 0.630703 & -0.5 & 10.59 & 10.59 & & 9.281 \\
\hline 5 & 0.59 & 4.10 & 0.541219 & -1.05 & 9.15 & 9.15 & & 8.581 \\
\hline 6 & 0.67 & 4.68 & 0.473972 & -1.5 & 8.05 & 8.05 & & 7.881 \\
\hline 7 & 0.75 & 5.26 & 0.421589 & -1.762 & 7.18 & 7.18 & 7.18 & 7.180 \\
\hline 8 & 0.83 & 5.84 & 0.379632 & -2.04 & 6.48 & 6.48 & 6.48 & 6.480 \\
\hline 9 & 0.92 & 6.42 & 0.34527 & -2.215 & 5.90 & 5.90 & & 5.780 \\
\hline 10 & 1.00 & 7.00 & 0.316613 & -2.4 & 5.42 & 5.42 & & 5.080 \\
\hline
\end{tabular}

\section{HASIL}

\section{Simulasi dan Analisis}

Pada tahap ini, simulasi rotor dengan metode BEM (Blade Element Momentum) meggunakan software Q-Blade v0.963 dilakukan untuk mendapatkan grafik pengaruh Coefficient Performa (Cp) terhadap Tip Speed Ratio (TSR), serta Daya (P) yang dihasilkan terhadap kecepatan angin (v). Diharapkan pada keadaan TSR 7 dan kecepatan angin $10 \mathrm{~m} / \mathrm{s}$, bilah dapat menghasilkan daya sebesar $\mathrm{P} \geq 500 \mathrm{~W}$. 
Setelah didapat parameter geometri bilah, dilakukan simulasi rotor dengan metode BEM (Blade Element Momentum) meggunakan software Q-Blade v0.963. Parameter yang dimasukkan saat simulasi yaitu jumlah iterasi sebanyak 1000 iterasi, denitas udara sebesar $1,225 \mathrm{Kg} / \mathrm{m} 3$, serta viskositas dinamik sebear 1,647 x 10-5 Ns/m2.

Hasil simulasi coefficient performa (CP) dibanding Tip Speed Ratio (TSR) terangkum pada Gambar 4. Berdasarkan hasil simulasi bilah memiliki Cp $52.5 \%$ pada TSR 5.

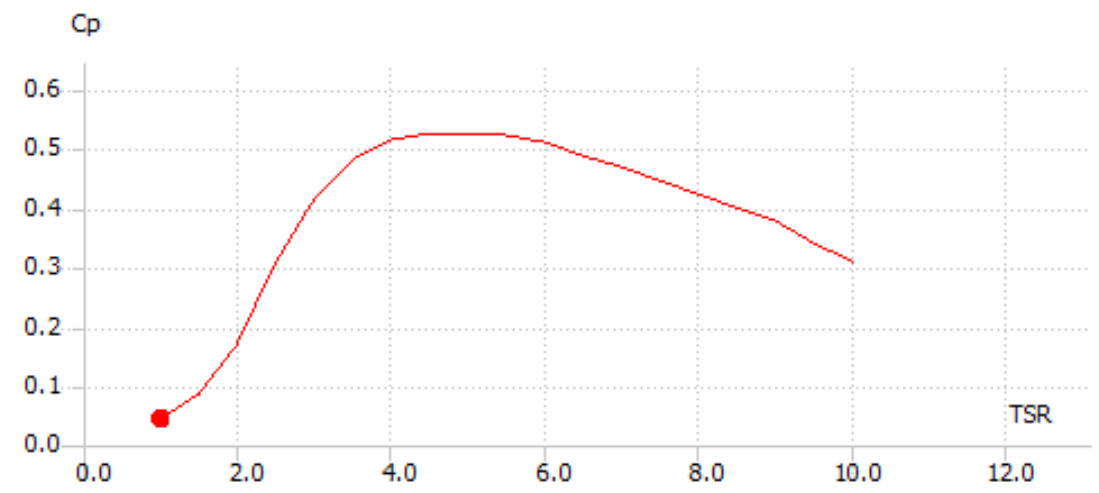

Gambar 4. Grafik coefficient performa terhadap TSR (Cp-TSR)

Kemudian dilakukan simulasi untuk melihat pengaruh kecepatan angin terhadap daya yang dapat dihasilkan pada berbagai kecepatan sudut, seperti tersaji dalam Gambar 5 berikut,

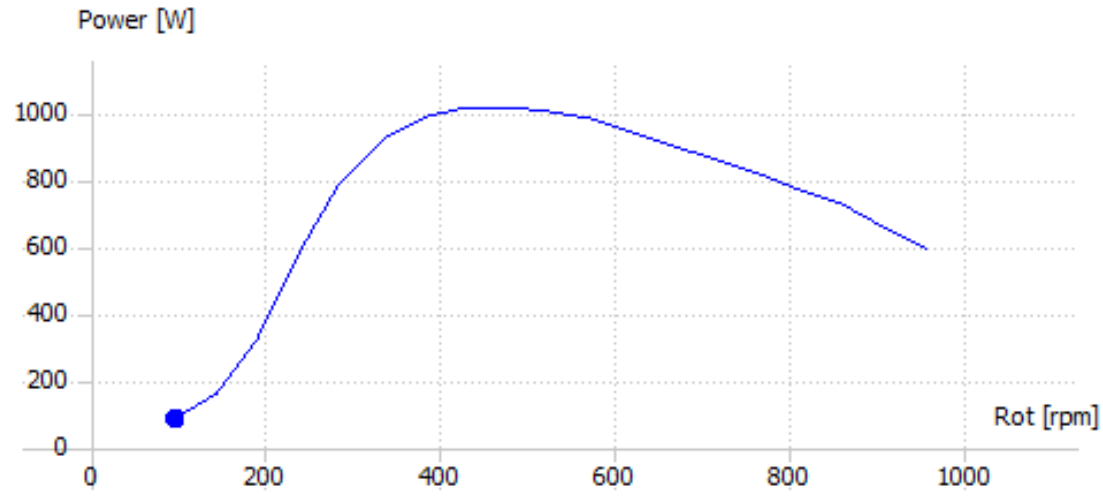

Gambar 5. Grafik kecepatan putar terhadap daya yang dihasilkan (P-v)

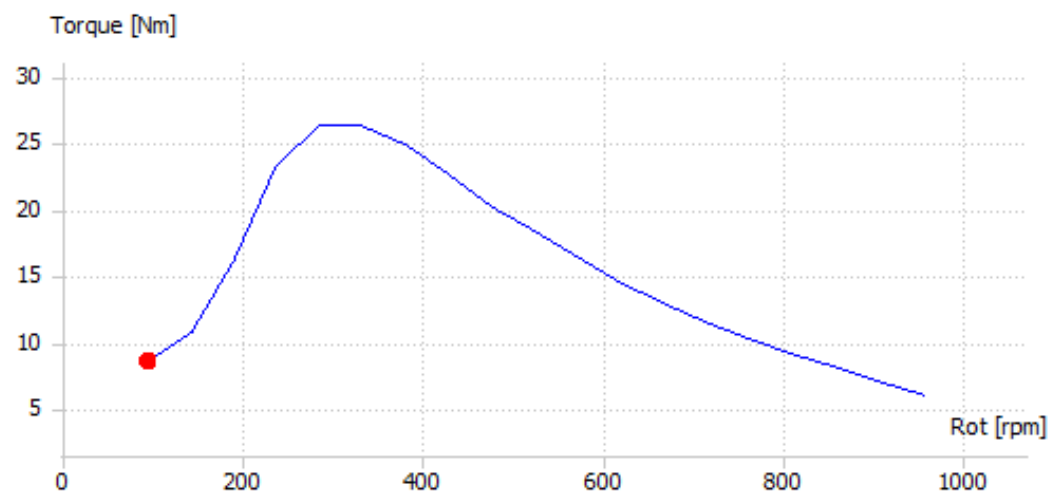

Gambar 6 Grafik torsi terhadap daya yang dihasilkan (P-v) 
Daya maksimum yang dihasilkan bilah pada kecepatan $10 \mathrm{~m} / \mathrm{s}$ adalah sebesar 1010 Watt ketika kecepatan sudut bilah $450 \mathrm{rpm}$. Daya minimum yang dihasilkan pada kecepatan 10m/s adalah sebesar $85 \mathrm{~W}$ ketika kecepatan sudut bilah $95 \mathrm{rpm}$. Rata-rata daya yang dihasilkan sebesar 547,5 W dalam kondisi kecepatan angina $10 \mathrm{~m} / \mathrm{s}$.

Hasil Simulasi diperkirakan NACA 4412 membutuhkan kecepatan awal yang kecil untuk memutar bilah yaitu $1 \mathrm{~m} / \mathrm{s}$ ketika kecepatan sudut bilah $100 \mathrm{rpm}$. Jenis bilah tipe taperless memiliki karakteristik lebih efektif digunakan ketika kecepatan angin rendah dan sedang. Bilah dengan jenis taperless lebih efisien dalam menangkap energi angin di bandingkan dengan bilah berjenis taper karena bilah taperless memiliki area sapuan penampang yang lebih luas karena memiliki chord yang sama dari pangkal ke ujung. sehingga daya tangkap energi angin untuk di konversi menjadi energi kinetik lebih besar. Akan tetapi bilah jenis ini memiliki kekurangan yaitu tidak tahan dalam kondisi badai karena rawan terjadi cracking.

\section{Validasi}

Pada tahap validasi ini bertujuan untuk membandingkan data hasil perancangan simulasi software dengan data real yang diambil dari observasi lapangan secara langsung.

Daya yang di hasilkan juga bergantung pada kecepatan angin yang sedang terjadi selama pengujian. Pada pengujian kali ini peralatan yang digunakan berupa: Turbin angin jenis HAWT tipe TSD 500, Controller, Data logger type Nedo2-04 dan Baterai 2V/800 Ah.

Data yang diambil dari Kincir Angin TSD 500 dengan bilah tipe Taperless menggunakan airfoil NACA 4412 pada 2 Februari 2020 ditunjukkan pada Tabel berikut

Tabel 3 Hasil Pengolahan Data Logger

\begin{tabular}{|c|c|c|c|c|c|}
\hline \multicolumn{7}{|c|}{ HASIL PENGOLAHAN DATA } \\
\hline NO & Time & Tegangan & Arus & Daya & NILAI ABSOLUT \\
\hline 1 & $12: 00: 01 \mathrm{AM}$ & 25.45 & -0.04 & -1.07 & 0.08 \\
\hline 2 & $12: 01: 01 \mathrm{AM}$ & 25.51 & 0.60 & 15.39 & 15.45 \\
\hline 3 & $12: 02: 01 \mathrm{AM}$ & 25.45 & 0.37 & 9.55 & 9.80 \\
\hline 4 & $12: 03: 01 \mathrm{AM}$ & 25.42 & -0.02 & -0.40 & 0.31 \\
\hline 5 & $12: 04: 01 \mathrm{AM}$ & 25.42 & 0.03 & 0.77 & 1.42 \\
\hline 6 & $12: 05: 01 \mathrm{AM}$ & 25.46 & 0.09 & 2.31 & 2.82 \\
\hline 7 & $12: 06: 01 \mathrm{AM}$ & 25.55 & 0.63 & 16.07 & 16.31 \\
\hline 8 & $12: 07: 01 \mathrm{AM}$ & 25.69 & 1.39 & 35.71 & 35.71 \\
\hline 9 & $12: 08: 01 \mathrm{AM}$ & 25.68 & 1.22 & 31.33 & 31.33 \\
\hline 10 & $12: 09: 01 \mathrm{AM}$ & 25.77 & 1.72 & 44.47 & 44.47 \\
\hline 1439 & $11: 58: 01 \mathrm{PM}$ & 0.00 & -23.99 & 0.00 & 0.00 \\
\hline 1440 & $11: 59: 01 \mathrm{PM}$ & 0.00 & -23.99 & 0.00 & 0.00 \\
\hline
\end{tabular}

Tabel 4 Data daya listrik hasil observasi lapangan

\begin{tabular}{|c|l|r|l|}
\hline \multirow{4}{*}{$\begin{array}{c}\text { Charging } \\
\text { Measurement }\end{array}$} & Maximum Battery Voltage & 30.31 & Volt \\
\cline { 2 - 4 } & Minimum Battery Voltage & 0.00 & Volt \\
\cline { 2 - 4 } & Maximum Charging Current & 19.91 & Ampere \\
\hline \multirow{3}{*}{$\begin{array}{c}\text { Charging } \\
\text { Power }\end{array}$} & Average Charging Wattage & 30.24 & Watt \\
\cline { 2 - 4 } & Maximum Charging Wattage & 585.58 & Watt \\
\cline { 2 - 4 } & Obtained Power & 725.55 & Wh \\
\hline
\end{tabular}


Hasil pengujian terangkum pada Tabel 4. Daya maksimum pengisian sebesar $585.58 \mathrm{~W}$ dan pengisian daya rata-rata sebesar $30.24 \mathrm{~W}$, dengan daya yang dihasilkan sebesar 725.55 Wh.

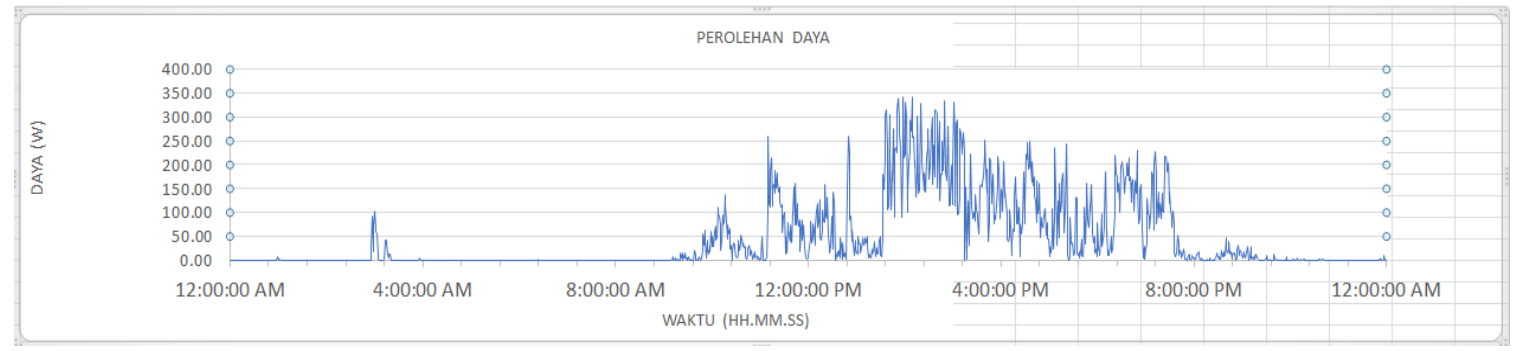

Gambar 7 Statistik daya yang dihasilkan per empat jam

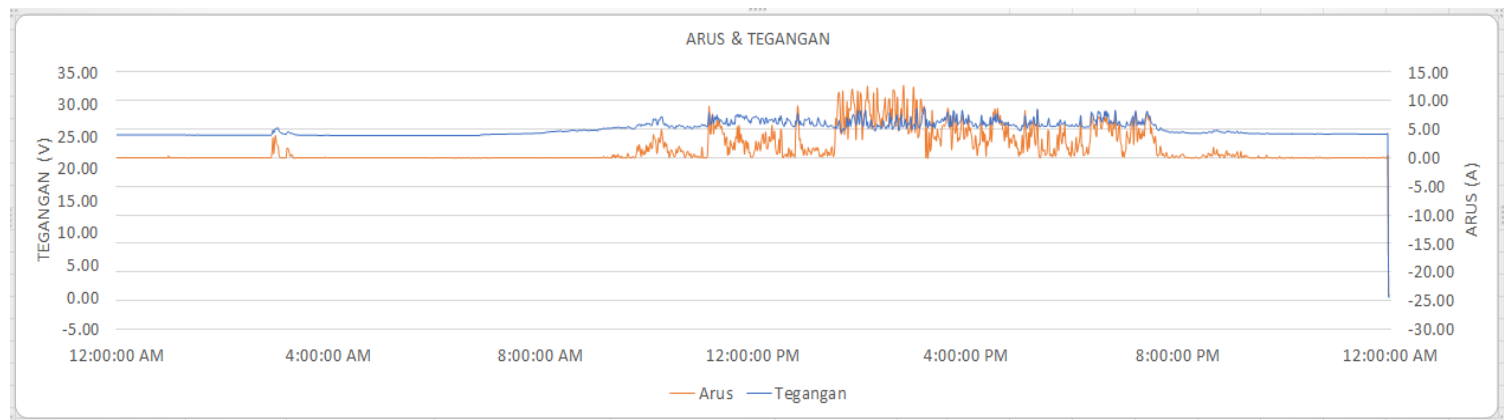

Gambar 8 Statistik Tegangan dan arus

\section{PEMBAHASAN}

Kecepatan angin rata rata tidak dapat dijadikan acuan dalam menentukan potensi energi angin pada suatu daerah, diperlukan studi lapangan secara langsung untuk melakukan penelitian awal dan pengambilan data untuk memastikan potensi angin di wilayah tersebut, dalam penelitian (Akbar Rachman, 2012) selama periode 2000-2007 kecepatan angin beberapa provinsi di Indonesia memiliki kecepatan rata-rata 2meter/s sampai 3 meter/s, maka dari itu pemanfaatan energi angin untuk setiap provinsi memerlukan penanganan yang berbeda dalam penerapannya. Baterai baru dapat digunakan apabila memiliki tegangan \pm 25 Volt, bilah berjenis taperless dengan airfoil NACA 4412 secara keseluruhan dapat menangkap energi angin \pm $30 \%$ dari energi yang tersedia. Manufacturing Bilah telah sesuai dengan perhitungan Tabel 1. Dimana nilai efisiensi sistem kincir angin sebesar 30\% dan pengujian secara langsung pun memiliki effisiensi serupa yaitu $\pm 30 \%$.

Perbedaan efisiensi hasil perancangan dan realita lapangan dapat terjadi karena banyak hal. Antara lain karena rugirugi daya yang terjadi pada bilah, generator, transmisi, sistem kelistrikan (kabel), dan human error saat perhitungan atau pembacaan skala.

\section{PENUTUP}

Berikut dapat diambil kesimpulan pada penelitian Kerja Praktik kali ini berdasarkan uraian yang telah dijelaskan sebelumnya : 1) Hasil perancangan bilah Taperless NACA 4412 memiliki panjang jari-jari $1 \mathrm{~m}$, lebar chord 0,12 m, dan twist angle $5,08^{\circ}-12.08^{\circ}$. 2) Bilah hasil perancangan, pada kecepatan angin $10 \mathrm{~m} / \mathrm{s}$ memiliki Cp maksimum $53 \%$, daya maksimum $1010 \mathrm{~W}$ pada kecepatan sudut $450 \mathrm{rpm}$, daya minimum $85 \mathrm{~W}$ pada kecepatan sudut $95 \mathrm{rpm}$. Rata-rata daya yang dihasilkan yaitu sebesar 547,5 W. 3) Hasil pengujian lapangan bilah Taperless NACA 4412, Hasil pengujian terangkum pada Tabel 4. Daya maksimum pengisian diperoleh sebesar $585.58 \mathrm{~W}$ dan pengisian daya rata-rata sebesar $30.24 \mathrm{~W}$, dengan daya yang dihasilkan sebesar $725.55 \mathrm{Wh}$.

\section{DAFTAR RUJUKAN}

A. Sanchez-Miralles, C. Calvillo, F. Martín, dan J. Villar,s. (2014). Use, Operation and Maintenance of Renewable Energy System vol. July 2014.

Akbar Rachman. (2012). analisis dan pemetaan potensi energ angin di indonesia. Depok: FT UI. 
Al-Shemmeri, T. (2010). Wind Turbines. T Al-shemmeri and Ventus Publisging Aps ISBN 978-87-7681-692-6.

Burhannudin Dahlan. (2016). Rancang Bangun Baling-Baling Kincir Angin NACA 4412 dan 4415 dari Bahan Kayu Mahoni (Swietenia macrophlylla) dan Pinus (Pinus merkusii). Surabaya: FAKULTAS MATEMATIKA DAN ILMU PENGETAHUAN ALAM INSTITUT TEKNOLOGI SEPULUH NOVEMBER.

C. Otieno Saoke . (2015). Am. J. Phys. Appl., vol. 3, no. 1 . Power Performance of an Inversely Tapered Wind Rotor and its Air Flow Visualization Analysis Using Particle Image Velocimetry (PIV), hal. 6.

G.Ingram. (2005). "Wind Turbine Blade Analysis using the Blade Element Momentum Method . Version 1 . 0 List of Figures," Power, no. c, hal. 1-21.

H. Gitano-Briggs. (2012). Adv. Wind Power. Low Speed Wind Turbine Design.

IEC 61400-2:2013. (2013). Wind Turbines-Part 2: Small Wind Turbine. Geneva.

J. F. Manwell, J. G. (2010). Wind Energy Explained: Theory, Design and Application .vol. 112, no. 483.

Kementerian Energi dan Sumber Daya Mineral. (2016). Jurnal Energi. Jurnal Energi, vol. 02, 100.

S. Liu dan I. Janajreh. (2012). Int. J. Energy Environ. Eng., vol. 3, no. 1. Development and application of an improved blade element momentum method model on horizontal axis wind turbines.

Tim Lentera Angin Nusantara. (2014). Pengenalan Teknologi Pemanfaatan Energi Angin. Tasikmalaya, Jawa Barat.

Tim Lentera Angin Nusantara. (2017). Profil Lentera Bumi Nusantara. Tasikmalaya, Jawa Barat.

Y. Nishizawa. (t.thn.). An Experimental Study of the Shapes of Rotor for Horizontal-Axis Small Wind Turbines. hal. no. 1. 